\title{
Applying Global History
}

\section{Globalization, Geopolitics, and the U.S.-China Rivalry after Covid-19}

\author{
Graeme A. Thompson \\ Ernest May Postdoctoral Fellow in History and Policy, John F. Kennedy \\ School of Government, Harvard University, Cambridge, MA, USA \\ gthompson@hks.harvard.edu
}

Received October 2020 | Accepted March 2021 | Published online April 8, 2021

\begin{abstract}
The Covid-19 crisis has prompted ongoing debates over the implications of the pandemic for the future of globalization, international order, and the deepening U.S.China strategic rivalry. Too often, however, these debates betray a disinclination to think historically about the nature of globalization. Yet globalization has deep historical roots, and its development and periodic crises throughout history have been closely linked to shifting geopolitical conditions. This article therefore argues and seeks to demonstrate that "global history," with its roots in the study of empires and transnational integration, provides a useful intellectual framework for better understanding the powerful forces currently reshaping the international system-most significantly geopolitical competition and economic decoupling between the United States and China in the age of Covid-19.
\end{abstract}

\section{Keywords}

global history - globalization - geopolitics - international order - United States China - Covid-19

\section{$\mathbf{1}$ \\ Introduction}

For a generation, globalization and American power defined international politics. With the fall of the Berlin Wall, foreign policymakers and international 
relations scholars began to grapple with the role of a hegemonic United States in an interconnected world that felt smaller than ever before. But even prior to the emergence of the novel coronavirus SARs-Cov-2 in Wuhan, China in late 2019, the tenor of debates over the future of globalization and America's role in the world had shifted markedly: from the "End of History," "the World is Flat," and America's "unipolar moment" to a fast-rising China, de-globalization, and a teetering international order. ${ }^{1}$ The ongoing Covid-19 pandemic has only intensified this trend. Talk of economic decoupling and a new Cold War is in the air, and as the U.S.-China rivalry deepens a palpable sense of anxiety and disorientation has descended upon foreign ministries around the world. ${ }^{2}$ How can we make sense of this precipitous unravelling?

Since the emergence of Covid-19 practically every issue in global politics has been refracted through the lens of the pandemic. "Hot takes" on the novel coronavirus have proliferated, and international relations experts are engaged in wide-ranging and often illuminating debates over the implications of the pandemic for globalization and the U.S.-led international order. In general, these have tended to converge on two key ideas. The first, that the pandemic has accelerated a series of pre-existing global trends, most notably great power competition between the United States and China, is widely accepted. ${ }^{3}$ The second, whether globalization as we have known it for the past three decades will survive, and if so in what form, hotly contested. ${ }^{4}$ Too often, however, these debates betray a disinclination to think historically about the nature of globalization. ${ }^{5}$ To be sure, historical perspectives on great power competition, inter-

1 See for example, "Globalisation is dead and we need to invent a new world order." The Economist, 28 June 2019.

2 Bruce Jones, "Balancing Act: Major Powers and the Global Response to Us-China Great Power Competition: A Brookings Interview." The Brookings Institution, July 2020.

3 See for example Richard Haass, "The Pandemic Will Accelerate History Rather than Reshape It." Foreign Affairs, April 7, 2020; Ian Bremmer and Cliff Kupchan, "Top Risks 2020: Coronavirus Edition." Eurasia Group, March 19, 2020; Rana Mitter, "Xi's World: How Covid has accelerated China's rise." The Spectator, October 24, 2020; Yves Tiberghien, "For the Global Economy, Us-China Rivalry Does Not Have to Mean Destruction." Global Asia 15 (2) (2020), 33-37.

4 For a selection of this debate, see Henry Farrell and Abraham Newman, "The Folly of Decoupling from China: It Isn't Just Perilous-It's Impossible." Foreign Affairs, June 3, 2020; Richard Fontaine, "Globalization Will Look Very Different After the Coronavirus Pandemic." Foreign Policy, April 17, 2020; "Has covid-19 killed globalisation?" The Economist, May 14, 2020; Michael A. Witt, "Prepare for the U.S. and China to Decouple." Harvard Business Review, June 26, 2020.

5 For a popular analysis of globalization that engages with history, see Jeffrey Sachs, The Ages of Globalization: Geography, Technology, and Institutions (New York: Columbia University Press, 2020). 
national order, and even pandemics have helped to illuminate and contextualize the current moment. ${ }^{6}$ But analyses of globalization, while rightly warning of the dangers and inefficiencies of U.S.-China "decoupling," nonetheless tend to underestimate the dynamic historical forces at work and to assume, in an almost teleological fashion, that if left to its own devices the global system would naturally continue to evolve towards ever-deeper integration and interconnectedness. $^{7}$

Yet the long-term development, contingencies, and periodic crises of globalization, and their connection to shifting geopolitical conditions, is familiar territory for historians. The circumstances that facilitated modern globalizationnamely unchallenged American primacy—no longer prevail, and it would be surprising if processes of global integration were unaffected. This article therefore contends that thinking historically about globalization and its relationship to geopolitics can help scholars and foreign policymakers better understand the powerful forces currently reshaping the international system. More specifically, I argue and aim to demonstrate that "global history," with its roots in the study of empires and transnational integration, provides a useful intellectual framework for examining the dynamics of globalization and international order in a world rocked by the Covid-19 pandemic and increasingly divided between the United States and China. The article proceeds in three parts. First, it introduces the main tenets of global history and briefly traces its emergence as a coherent approach to analyzing the historical development of global integration and interconnectedness. The second section illustrates the utility of global history by highlighting its application to three distinct historical examples of crises of globalization and shifts in international order. The third section then turns to the present, applying a global historical approach to examine the long-term causes and consequences of the burgeoning U.S.-China strategic rivalry. This focuses on the potential development of globalization in the context of deepening geopolitical competition and the sudden shock of the Covid-

6 See for example Seth Center and Emma Bates, eds. After Disruption: Historical Perspectives on the Future of the International Order (Washington: Center for Strategic and International Studies, September 2020); Andrew Erhardt, "Disease and Diplomacy in the 19th Century." War on the Rocks, April 30, 2020; Kyle Harper, "The Coronavirus is Accelerating History Past the Breaking Point." Foreign Policy, April 6, 2020; Margaret MacMillan, "The World after Covid: A Perspective from History." In Covid-19 and World Order: The Future of Conflict, Competition, and Cooperation, eds. Hal Brands and Francis J. Gavin (Baltimore: Johns Hopkins University Press, 2020), ch. 2; A. Wess Mitchell and Charles Ingrao, "Emperor Joseph's Solution to Coronavirus." The Wall Street Journal, April 6, 2020.

7 See for example Farrell and Newman, "The Folly of Decoupling From China"; Keith Johnson and Robbie Gramer, "The Great Decoupling." Foreign Policy, May 14, 2020. 
19 pandemic. Finally, it concludes by echoing calls for more a more historically informed U.S. foreign policy, including through the application of global history.

In recent years, global history has emerged as perhaps the dominant, and certainly the fastest growing, approach to academic historical inquiry. The year 2020 alone saw the publication of global histories of everything from military strategy and the Napoleonic Wars to money, democracy, and even beans. ${ }^{8}$ As Harvard historian David Armitage provocatively argued in 2012, "If you are not doing an explicitly transnational, international or global project, you now have to explain why you are not."9 But what precisely is global history, given that it "cannot usefully mean the history of everything, everywhere, all the time,"10 and what exactly are its intellectual origins?

Global history, in short, is a broad methodological approach that challenges the centrality of national narratives and Western perspectives through "a form of historical analysis in which phenomena, events, and processes are placed in global contexts."11 This "global turn" in historical scholarship was prompted, in part, by the end of the Cold War and the rise of globalization and American hegemony, which raised new historical questions but also accelerated the decline of traditional diplomatic and international history. ${ }^{12}$ "Historians quickly responded to the fall of the Berlin Wall, the crumbling protective ram-

8 Jeremy Black, Military Strategy: A Global History (New Haven: Yale University Press, 2020); Alexander Mikaberidze, The Napoleonic Wars: A Global History (Oxford: Oxford University Press, 2020); Akinobu Kuroda, A Global History of Money (London: Routledge, 2020); Natalie Rachel Morris, Beans: A Global History (London: Reaktion Books, 2020); David Stasavage, The Decline and Rise of Democracy: A Global History from Antiquity to Today (Princeton: Princeton University Press, 2020).

9 Martine van Ittersum and Jaap Jacobs, "Are We All Global Historians Now? An Interview with David Armitage," Itinerario 36 (2) (2012), 16 [emphasis in original].

10 James Belich, John Darwin, and Chris Wickham, "Introduction." In The Prospect of Global History, eds. James Belich, John Darwin, Margret Frenz, and Chris Wickham (Oxford: Oxford University Press, 2016), 3.

11 Sebastian Conrad, What is Global History? (Princeton: Princeton University Press, 2016), 5.

12 On the trajectory of international relations history, see George C. Herring, "A sHAFR Retrospective." Diplomatic History 31 (3) (2007), 397-400; Adam Chapnick, "Where have all of Canada's diplomatic historians gone?" International Journal 65 (3) (2010), 725-737; Michael J. Hogan, "The 'Next Big Thing': The Future of Diplomatic History in a Global Age." Diplomatic History 28 (1) (2004), 1-21. 
parts of national capitalism, the boom in container shipping, and the rise of the cosmopolis," historian Jeremy Adelman recalls. "What was global was not the object of study, but the emphasis on connections, scale and, most of all, integration."13 Indeed one of the leading approaches to global history is the attempt to explain the historical development of transnational integration and interconnectedness, and the movement of people, goods, capital, ideas, and even pathogens across political and cultural boundaries. ${ }^{14}$ As practitioners argue, "Globalization is a term that needs to be rescued from the present and salvaged for the past. To define it as always encompassing the whole planet is to mistake the current outcome for a very ancient process." ${ }^{15}$

Understood in this way, globalization has deep historical roots that are entwined with the rise and fall of empires and great powers. ${ }^{16}$ Throughout history empires rather than nation-states have been the world's primary strategic actors, and imperial systems like the Roman or British, though ultimately based on coercion and force, provided the relatively stable political orders within which complex economic and cultural integration took place. ${ }^{17}$ Global history, too, at least as it developed in Britain and the United States, has origins in imperial history. Yet the history of empire in the Anglophone world was for many decades entangled with Western and particularly British imperialism. The lessons gleaned from empires past and their application to the development of the British empire were central preoccupations for historians trained in Oxford and Cambridge in the late-19th and early-2oth centuries. ${ }^{18}$ But like

13 Jeremy Adelman, "What is global history now? Historians cheered globalism with work about cosmopolitans and border-crossing, but the power of place never went away." Aeon, March 2, 2017.

14 On comparative, transnational, postcolonial, and other approaches to global history, see Conrad, What is Global History?, 37-61.

15 Belich, Darwin, and Wickham, "Introduction," 3. See also A.G. Hopkins, ed., Globalization in World History (London: Pimlico, 2002) and Jürgen Osterhannel and Niels P. Petersson, Globalization: A Short History (Princeton: Princeton University Press, 2005).

16 As P.J. Cain and A.G. Hopkins argue: "There is now a strong case for placing imperialism and empires at the centre of the study of world history and specifically the history of globalization." P.J. Cain and A.G. Hopkins, British Imperialism, 1688-200o (London: Longman, 2002 [1993]), 664.

17 See especially Cain and Hopkins, British Imperialism; Martin Pitts and Miguel John Versluys, eds. Globalisation and the Roman World: World History, Connectivity, and Material Culture (Cambridge: Cambridge University Press, 2014).

18 See for example James Bryce, The Ancient Roman Empire and the British Empire in India, The Diffusion of Roman and English Law Throughout the World: Two Historical Studies (Oxford: Oxford University Press, 1914); Lionel Curtis, The Problem of the Commonwealth (London: Macmillan, 1915); J.R. Seeley, The Expansion of England: Two Courses of Lectures (London: Macmillan, 1883). On British imperial historiography, see especially Dane 
so many empires, in the second half of the 2oth century imperial history suffered a precipitous decline and fall. With decolonization British and European historians turned away from the study of empire and global connections, focusing instead on national, regional, and local histories as well as processes of European integration. Historians in the former European colonies, meanwhile, followed the American path in seeking to recover or create newly independent and post-colonial national narratives. ${ }^{19}$

With the onset of America's unipolar moment, the rise of emerging economies, and the so-called Washington consensus after 1989, however, debates over empire and global connections returned to the forefront of historical scholarship. Though international order and increasing globalization now rested on a system of nation-states and international institutions where the United States, at least in theory, was only first among equals, the vast extent of American power seemed to dwarf even the Roman and British empires. ${ }^{20}$ In this context, historian A.G. Hopkins published a prescient article calling for a revitalized imperial history prepared to grapple with "transnational influences, known collectively as globalization."21 In the two decades that followed, the "global turn" transformed historical scholarship. New works employing a global approach, including to the study of empire, became important historiographical landmarks. ${ }^{22}$ Scholars worldwide embraced global history as a means to

Kennedy, "The Imperial History Wars." Journal of British Studies 54 (2015), 5-22 and William Roger Louis, "Introduction." In The Oxford History of the British Empire: Volume v: Historiography, eds. William Roger Louis and Robin Winks (Oxford: Oxford University Press, 1999). For Oxford historians and empire, Richard Symonds, Oxford and Empire: The Last Lost Cause? (Oxford: Clarendon Press, 1986), chs. 2-3.

19 On these historiographical shifts, see especially David Fieldhouse, "Can Humpty-Dumpty Be Put Together Again? Imperial History in the 1980s." The Journal of Imperial and Commonwealth History 12 (2) (1984), 10; A.G. Hopkins, American Empire: A Global History (Princeton: Princeton University Press, 2018), ch. 1; and J.G.A. Pocock, "British History: A Plea for a New Subject." The Journal of Modern History 47 (4) (1975), 6o1-621.

20 On the theme of American empire during this period, see for example: Niall Ferguson, Colossus: The Rise and Fall of the American Empire (New York: Penguin, 2004); Michael Ignatieff, Empire Lite: Nation Building in Bosnia, Kosovo and Afghanistan (Toronto: Penguin, 2003); Patrick O'Brien and Armand Cleese, eds. Two Hegemonies: Britain 1846-1914 and the United States 1941-2001 (Aldershot, UK: Ashgate, 2002); Ali Parchami, Hegemonic Peace and Empire: The Pax Romana, Britannica, and Americana (London: Routledge, 2009).

21 A.G. Hopkins, "Back to the Future: From National History to Imperial History." Past \& Present 164 (1999), 202.

22 See for example David Armitage, The Declaration of Independence: A Global History (Cambridge, MA: Harvard University Press, 2008); C.A. Bayly, The Birth of the Modern World, 1780-1914: Global Connections and Comparisons (Oxford: Blackwell, 2004); Sven Beckert, Empire of Cotton: A Global History (New York: Alfred A. Knopf, 2014); John Darwin, After 
challenge Eurocentric perspectives and broaden understanding of the development of diverse, interconnected human societies. ${ }^{23}$ And academic journals and research centers dedicated to global history proliferated, with Oxford, the home of imperial history, establishing its own Centre for Global History in 2011. ${ }^{24}$

Yet the relationship between global, imperial, and international history remains somewhat ambiguous. Global and to some extent imperial historians imbibed earlier movements towards cultural and social history, with a corresponding tendency to emphasize subjects like migration and identity while avoiding and marginalizing politics, diplomacy, and war. ${ }^{25}$ Some imperial historians, meanwhile, remained interested in geopolitics and processes of empire-building (as well as their decline). ${ }^{26}$ And international historians continued to illuminate inter-state relations, especially as Cold War-era documents became available. ${ }^{27}$ But imperial and international historians also benefited from the intellectual cross-pollination of global history. New studies of "America in/and the world," for instance, encompass a broad range of domestic and transnational factors that contributed to shaping U.S. engagement internationally. ${ }^{28}$ The Cold War, too, is now regularly seen and studied in global contexts. ${ }^{29}$

Tamerlane: The Rise and Fall of Global Empires, 1400-200o (London: Penguin, 2008); Jürgen Osterhammel, The Transformation of the World: A Global History of the Nineteenth Century (Princeton: Princeton University Press, 2014).

23 On the development of global history worldwide, see especially Sven Beckert and Dominic Sachsenmaier, eds., Global History, Globally: Research and Practice Around the World (London: Bloomsbury, 2018); and Dominic Sachsenmaier, Global Perspectives on Global History: Theories and Approaches in a Connected World (Cambridge: Cambridge University Press, 2011).

24 Robert S.G. Fletcher, Benjamin Mountford, and Simon J. Potter, "Making Connections: John Darwin and his Histories of Empire." The Journal of Imperial and Commonwealth History 47 (5) (2019), 807 .

25 For a version of this critique, see Rachael Bright and Andrew Dilley, "Historiographical Review: After the British World." Historical Journal 6o (2) (2017), 547-568.

26 For instance, John Darwin, Britain and Decolonisation: The Retreat from Empire in the PostWar World (Basingstoke, uk: Macmillan, 1988), and "Imperialism and the Victorians: The Dynamics of Territorial Expansion." The English Historical Review 112 (447) (1997), 614-642.

27 For a recent example, see Simon Miles, Engaging the EvilEmpire: Washington, Moscow, and the Beginning of the End of the Cold War (Ithaca: Cornell University Press, 202O).

28 See for example Jay Sexton and Kristin Hoganson, eds. Crossing Empires: Taking U.S. History into Transimperial Terrain (Durham, NC: Duke University Press, 2020) and Jay Sexton, "The Global View of the United States," The Historical Journal 48 (1) (2005), 261-276. For similar developments elsewhere, see Patrick Boucheron and Stephane Gerson, eds. France in the World (Paris: Other Press, 2019) and Asa McKercher, Canada and the World Since 1867 (London: Bloomsbury, 2019).

29 Odd Arne Westad, The Cold War: A World History (New York: Basic Books, 2017). 
And it is no longer credible to write histories of empire that overlook the globalizing influence of imperial networks that distributed "credit, capital, goods, information, manpower, and protection on a global basis." 30

Yet the movement away from politics, statecraft, and military history, as well as national histories more generally, entailed some negative consequencesamong them declining appreciation for the importance of strategic affairs in shaping the modern world. ${ }^{31}$ As historian Margaret MacMillan observes, "in the majority of Western universities the study of war is largely ignored ... It is a curious neglect, because we live in a world shaped by war."32 Hal Brands and Francis Gavin similarly lament that historians have become "steadily less relevant to addressing critical matters of politics, diplomacy, and war and peace." ${ }^{33}$ To some extent this is beginning to be redressed, and growing interest in applied history and grand strategy is particularly welcome in that regard. ${ }^{34}$ Practitioners of global history, moreover, have been warned against rose-tinted cosmopolitanism and cheerleading for globalization while ignoring or downplaying the importance of the un-connected, local, and particular. ${ }^{35}$ Surely in light of the Covid-19 pandemic — with its associated border closures and massive government interventions-and growing tensions between the United States and China, it is clear that state sovereignty and great power politics have not disappeared. At its best, however, global history highlights the connections as well as the tensions between the local and the global, broadens and deepens our perspectives on the human experience, and forces us to incorporate transnational factors and phenomena in analyses of global affairs. In so doing, it provides an important intellectual framework for understanding

30 John Darwin, The Empire Project: The Rise and Fall of the British World-System, 1830-1970 (Cambridge: Cambridge University Press, 2009), 144.

31 See Max Hastings, "American Universities Declare War on Military History." Bloomberg, 31 January 2021; Fredrik Logevall and Kenneth Osgood, "Why Did We Stop Teaching Political History?" New York Times, August 29, 2016.

32 Margaret MacMillan, War: How Conflict Shaped Us (New York: Random House, 2020), xv.

33 Hal Brands and Francis J. Gavin, "The Historical Profession is Committing Slow-Motion Suicide." War on the Rocks, 10 December 2018.

34 Graham Allison and Niall Ferguson, "Applied History Manifesto," October 2016, https:// www.belfercenter.org/project/applied-history-project\#!manifesto, accessed October 20, 2020. For debates over "grand strategy," see Thomas Meaney and Stephen Wertheim, "Grand Flattery: The Yale Grand Strategy Seminar." The Nation, May 9, 2020, and William James, "Grandiose Strategy? Refining the Study and Practice of Grand Strategy." The RUSI Journal 165 (3) (2020), 74-83.

35 Jeremy Adelman, "What is global history now?"; J.G.A. Pockock, "On the Unglobality of Contexts: Cambridge Methods and the History of Political Thought." Global Intellectual History 4 (1) (2019), 1-14. 
the development, working, and even disruption of long-established patterns of integration and international order.

\section{Globalization, Empire, and International Orders in History}

"Empire," as historian John Darwin observes, "has been the default mode of political organization throughout most of history. Imperial power has usually been the rule of the road." 36 Yet despite their ubiquity, the definition of an empire-and its distinction from a hegemon or great power-is notoriously slippery. ${ }^{37}$ Classically, empires comprise formal geographic spaces where a dominant power forcefully incorporates territory, uniting diverse populations in hierarchical, "multi-ethnic conglomerates held together by transnational organizational and cultural ties." 38 More subtly and expansively, empires can also be informal zones of influence where economic or political pressure effectively curtails the autonomy of an otherwise independent state. ${ }^{39}$ Meanwhile, the term "hegemony" - preferred by International Relations scholars - is generally used "to refer to political and other forms of leadership exercised by a single state." ${ }^{40}$ What unites these forms of state power is their role in creating and upholding international political orders that can facilitate connection, exchange, and integration between disparate peoples and regions of the world.

Empires and hegemons, of course, are neither necessary nor sufficient for globalization and international order. The Concert of Europe, for example, functioned as an international system composed of relatively evenly-matched great powers that both competed and cooperated within a defined geographical and political context. ${ }^{41}$ Processes of globalization, moreover, have "been the work of many hands, and many agents" besides the state, including mer-

36 Darwin, After Tamerlane, 23.

37 See for example Niall Ferguson, "Hegemony or Empire?" Foreign Affairs 82 (5) (2003), 154161 and Hopkins, American Empire, 707-721.

38 Cain and Hopkins, British Imperialism, 664.

39 The classic account of informal empire remains John Gallagher and Ronald Robinson, "The Imperialism of Free Trade." The Economic History Review 6 (1) (1953), 1-15.

40 Hopkins, American Empire, 30. For a recent discussion of the concept of hegemony in International Relations, see G. John Ikenberry and Daniel H. Nexon, "Hegemony Studies 3.o: The Dynamics of Hegemonic Orders." Security Studies 28 (3) (2019), 395-421.

41 Ian Clark argues that this was a form of "collective hegemony" in Ian Clark, Hegemony in International Society (Oxford: Oxford University Press, 2011), ch. 4. See also Brendan Simms, Europe: The Struggle for Supremacy from 1453 to the Present (New York: Basic Books, 2013), ch. 4 and Glenda Sluga, "Inventing an International Order: Lessons from 200 Years Ago." In After Disruption, 11-16. 
chants, migrants, and missionaries whose activities continue under conditions of instability, albeit with greater difficulty. ${ }^{42}$ And some international orders, such as the bipolar world of the Cold War, to which we shall return, are less conducive to transnational integration. Nevertheless, imperial and hegemonic powers have often served as "globalizing forces" that, by enforcing international stability and lowering or eliminating barriers to movement and exchange, encourage connectivity to deepen and accelerate. ${ }^{43}$ Yet the flip side of integration is the ever-present prospect of disintegration and even collapse. Complex networks of exchange can become rigid through overspecialization and dependence on far-flung resources or markets, leaving them vulnerable to sudden disruptions. ${ }^{44}$ Over time, globalized systems also simply evolve with shifting geopolitical, economic, social, and ecological conditions. As A.G. Hopkins argues, globalization has not only been facilitated by empires, but has evolved in stages in which "successful expansion created countervailing or competing forces" that undermined and overturned established structures and patterns. ${ }^{45}$ "While at some periods globalization might appear to be a linear process," the late historian C.A. Bayly agreed, "it was at best a very discontinuous one." 46

Three very different historical examples illustrate the vicissitudes of globalization and international order. In 1177 BC: The Year Civilization Collapsed (2014), archaeologist and ancient historian Eric Cline applies the tools and perspectives of global history to re-examine the rapid and synchronized decline of the late-Bronze Age civilizations of the eastern Mediterranean, including Mycenean Greece and the Egyptian empire at its zenith. In his path-breaking account, these ancient civilizations comprised a pre-modern globalized system premised on the exchange of copper and tin - the essential but geographically dispersed resources needed to forge bronze - as well as agricultural and luxury goods across vast distances. These extensive trade and cultural links, proven through archeological evidence and contemporary accounts, suggest a system characterized by circulation and connectivity. "Here," Cline argues, "we are considering a globalized world system with multiple civilizations all interacting and at least partially dependent upon each other." ${ }^{\text {"7 }}$ The notion of "archaic

\footnotetext{
42 John Darwin, "Afterword: History on a Global Scale." In The Prospect of Global History, 179.

43 Hopkins, American Empire, 12.

44 See for example the "cotton famine" in Lancashire during the U.S. Civil War in Beckert, Empire of Cotton, ch. 9.

45 Hopkins, American Empire, 32.

46 C.A. Bayly, "'Archaic' and 'Modern' Globalization in the Eurasian and African Arena, c. 1750-1850." In Hopkins, ed., Globalization in World History, 49.

47 Eric H. Cline, 1177 BC: The Year Civilization Collapsed (Princeton: Princeton University Press, 2014), xvi.
} 
globalization," in which "globalizing networks were created by great kings and warriors ... by religious wanderers and pilgrims ... and by merchant princes and venturers pursuing profit amidst risk across borders and continents," seems appropriate in this case. ${ }^{48}$ As Cline suggests, moreover, "it may have been this very internationalism that contributed to the apocalyptic disaster that ended the Bronze Age." 49 When parts of the region faced a series of military assaults, droughts, earthquakes, social unrest, and resulting trade disruptions in the 12th century вСЕ, the cascading effects led the advanced and interconnected societies to crumble and in some cases to disappear entirely.

Fast forward roughly 2400 years to the "Global Middle Ages" of the 13th and 14th centuries. ${ }^{50}$ Asia was the center of the world economy, and the ancient Silk Roads linked vast swathes of the earth-from China through Central Asia and the Middle East to Europe-in networks of trade that facilitated cultural, religious, and intellectual exchange. Mediterranean city states like Genoa and Venice, alongside fabled Central Asian cities like Samarkand and Bukhara, grew rich as cosmopolitan commercial entrepots along the trade routes. As historian Peter Frankopan argues, "There was good reason why the cultures, cities, and peoples who lived along the Silk Roads developed and advanced: as they traded and exchanged ideas, they learnt and borrowed from each other, stimulating further advances in philosophy, the sciences, language and religion."51

But the trade routes that conveyed silver, silks, and spices also carried soldiers and pathogens. In the 120os the Mongol armies of Genghis Khan and his successors swept across Eurasia, reaching the gates of Vienna in 1241, sacking Baghdad in 1258, and subduing the whole of China by the 1270s, where they built a new imperial capital, Beijing. ${ }^{2}$ The period of archaic globalization that developed along the Silk Roads was thus "set back by the fall of ancient empires and the Mongol invasions." ${ }^{53}$ Despite their fearsome reputation, however, the Mongols ultimately ushered in a new period of relative geopolitical stability,

48 A.G. Hopkins, "Introduction: Globalization-An Agenda for Historians." In Hopkins, ed., Globalization in World History, 4.

49 Cline, $1177 B C ., 171$.

50 Catherine Holmes and Naomi Standen, eds. The Global Middle Ages (Oxford: Oxford University Press, 2018) and Robert I. Moore, “A Global Middle Ages?” In The Prospect of Global History, ch. 4.

$5^{1} \quad$ Peter Frankopan, The Silk Roads: A New History of the World (New York: Vintage Books, 2017 [2015]), xvii.

52 Ibid., 159-163.

53 Bayly, "'Archaic' and 'Modern' Globalization in the Eurasian and African Arena, c. 17501850 ," 49 . 
religious tolerance, and economic transformation across Eurasia. ${ }^{54}$ The Mongol empire, in other words, was a globalizing force that facilitated integration through the "protection [it] offered to international trade." 55 Indeed, under the Pax Mongolica "not only the Mongols but Asia as a whole entered Europe's field of vision," ${ }^{\prime 6}$ and Genoese and Venetian merchants expanded their roles in transcontinental commerce "through treaties with, and political support from, the Mongol authorities." 57

Yet accelerating integration across Eurasia also enabled the spread the Black Death that followed in the Mongols' wake. By 1345 the plague reached Europe, where it killed up to one-half of the population in multiple waves over decades. ${ }^{58}$ One of the longer-term consequences of mass death in Europe, however, were severe labour shortages that soon raised wages. Post-plague Europe, as historian James Belich notes, saw "increasing specialization and trade ... an upsurge in labour-saving practices" that boosted productivity, and an increased demand for luxury goods. ${ }^{59}$ This gave impetus to lucrative trade and raiding missions that proliferated in the early $1400{ }^{60}{ }^{6}$ Meanwhile, the far-flung Mongol empire, reorganized under Tamerlane, fractured and dissolved, a new Chinese dynasty turned inward, and the rising Ottoman empire conquered Constantinople, on which Europeans had largely depended for access to Asia. ${ }^{61}$ In this context, Genoese merchants turned west to leverage their networks in Portugal and Spain and set out in search of new trade routes by sea. Throughout the 140os Iberian sailors extended their reach to the Atlantic islands and down the coast of Africa until Genoese mariner Christopher Columbus set out west in search of India and Portuguese navigator Vasco de Gama arrived in the subcontinent via the Cape of Good Hope. ${ }^{62}$ In short, not only did military conquest and empire under the Mongols promote a new period of Eurasian globalization, but the subsequent experience of plague and geopolitical upheaval contributed to a decisive shift in global trade that launched the European empires and remade the world.

54 Ibid., $173^{-176 .}$

55 Nicola Di Cosmo, "Black Sea Emporia and the Mongol Empire: A Reassessment of the Pax Mongolica." Journal of the Economic and Social History of the Orient 53 (1-2) (2010), 104.

$5^{6}$ Frankopan, The Silk Roads, 177-178.

57 Di Cosmo, "Black Sea Emporia and the Mongol Empire," 98.

$5^{8}$ James Belich, "The Black Death and the Spread of Europe," in The Prospect of Global History, 95-96.

59 Ibid., 99-100.

6o Ibid., 101-103. See also Frankopan, The Silk Roads, 186-19o.

61 Frankopan, The Silk Roads, 190-194; Darwin, After Tamerlane, 33-45.

62 Belich, "The Black Death and the Spread of Europe," 104-105; Darwin, After Tamerlane, 51-65; Frankopan, The Silk Roads, 197-207. 
Almost 400 years later the British empire was at its height in the late 19th century. From inauspicious origins the empire on which the sun never set became the largest in world history. ${ }^{63}$ Following the defeat of France in the Seven Years' War and the subsequent loss of the American colonies in 1783 , the powerful British fiscal-military state extended its reach through a system of mercantilist "proto-globalization based on agriculture, commerce, and dynastic rule" that soon encircled the globe. ${ }^{64}$ By the first half of the 19th century, the abolition of mercantilism and its replacement by free trade, combined with technological innovation, institutional reforms, and a relatively permissive international environment, facilitated continued British expansion and the emergence of a truly modern, globalized empire. ${ }^{65}$ Indeed, amid the violence and oppression of imperialism, the Pax Britannica encompassed an integrated world-system premised on British naval supremacy, fueled financially by the City of London, and bound together by revolutionary technologies like railways, steamships, and the telegraph. This multifaceted empire of empires "embraced an extraordinary range of constitutional, diplomatic, political, commercial, and cultural relationships ... [that] formed the real source of British world power." 66 While the Royal Navy imposed international order beyond Europe at the point of a gunboat, people, goods, and capital crossed borders and circled the globe at increasing velocity and in growing numbers. ${ }^{67}$ This was globalization at a level to which, by some measures, we only recently returned. ${ }^{68}$

Yet by the turn of the 2oth century globalization and the British world order on which it depended was under growing strain. Rising great powers like Germany, Japan, and the United States - which benefited from the international stability enforced by the British - sought their own economic and imperial spheres of influence. After 1870, the geopolitical context shifted rapidly towards

63 On the early British Empire, see David Armitage, The Ideological Origins of the British Empire (Cambridge: Cambridge University Press, 2000).

64 Hopkins, American Empire, 94. On this period, see C.A. Bayly, Imperial Meridian: The British Empire and the World, 1780-1830 (London: Routledge, 1989), 100-132; Cain and Hopkins, British Imperialism, 1688-200o, 76-103.

65 Darwin, The Empire Project, 23-63.

66 Ibid., $1-2$.

67 For an introduction to globalization and the British Empire, see especially: James Belich, Replenishing the Earth: The Settler Revolution and the Rise of the Anglo-World, 1783-1939 (Oxford: Oxford University Press, 20o9); Cain and Hopkins, British Imperialism; Gary Magee and Andrew Thompson, Empire and Globalisation: Networks of People, Goods, and Capital in the British World, c. 1850-1914 (Cambridge: Cambridge University Press, 2010).

68 Laurence Chandy and Brina Seidel, "Is globalization's second wave about to break?" Brookings Institution, October 4, 2016. 
increased great power competition. ${ }^{69}$ During this period there was a marked surge in political and ideological commitment to protectionism, nationalism, and militarism, and the relatively free movement of people and capital collided with wealth inequality and racist ideologies to fuel populist and antiimmigrant sentiment. In Britain itself this took the form of the "New Imperialism," which reflected weariness with liberal orthodoxies like free trade and the belief that London needed to consolidate its empire and reinvigorate its industrial economy in order to compete with new imperial rivals. ${ }^{70}$ By 19oo, Germany was pursuing a "world policy" intent on developing its navy and overseas empire, and British strategic policy adjusted to concentrate on the rising German threat. ${ }^{71}$ Despite being each other's largest trading partner, the AngloGerman antagonism intensified and was enmeshed in Europe's complex, interlocking system of alliances. Subsequent events are infamous. In August 1914, Germany invaded France through neutral Belgium, which Britain was committed to defend, and the integrated world of 19th century globalization collapsed into a generation of total war, depression, and revolution that lasted until $1945{ }^{72}$

As this cursory historical tour should demonstrate, globalization is not a one-way street, empires, great powers, and international orders do not last forever, and history is almost never linear or unidirectional.

\section{Applying Global History in 2021}

What, then, is the significance of these examples for the present? And what can a global historical approach tell us about the U.S.-China rivalry, the Covid19 crisis, and their implications for globalization and international order? At least three facts are apparent. First, globalization can end in crisis. The admit-

69 Paul Kennedy, The Rise of the Anglo-German Antagonism, 1860-1914 (London: Allen \& Unwin, 1980); Cees Heere, Empire Ascendant: The British World, Race, and the Rise of Imperial Japan, 1894-1914 (Oxford: Oxford University Press, 2019); Hopkins, American Empire, chs. $7-8$.

70 Darwin, The Empire Project, 92-111. See also Duncan Bell, The Idea of Greater Britain:Empire and the Future of World Order, 1860-19oo (Princeton: Princeton University Press, 2007).

71 John Bew, Realpolitik: A History (Oxford: Oxford University Press, 2015), 79-106; David Morgan-Owen, The Fear of Invasion: Strategy, Politics, and British War Planning, 1880-1914 (Oxford: Oxford University Press, 2017).

$7^{2}$ On the causes of the Great War, see Christopher Clark, The Sleepwalkers: How Europe Went to War in 1914 (London: Allen Lane, 2012) and Margaret MacMillan, The War That Ended Peace: The Road to 1914 (New York: Random House, 2013). 
tedly fragmentary evidence around the Bronze Age collapse suggests that a combination of factors, perhaps singularly insufficient to provoke a systemic crisis, can lead complex, interconnected systems to disintegrate. The example of the British world-system, conversely, shows that geopolitical tensions can destroy the conditions that facilitate integration. Second, shifting geopolitical circumstances can create economic incentives that prompt existing systems of exchange to adapt and evolve. The Mongol conquests intensified economic integration across Eurasia, while the upheaval that followed their imperial collapse encouraged $15^{\text {th }}$ century European merchants to seek alternative trade routes that ultimately gave rise to a new, maritime system of globalization and world order. And third, exogenous factors like plague and natural disasters can catalyze historical shifts. In sum, as John Darwin argues:

We might even propose that globalization (in any period) has been subject to episodes-if not whole eras-of crisis, when the interaction between its various components triggered unmanageable tensions or when the "manic" phase of economic expansion gave way to panic, autarchy, or aggression ... We might also observe the apparent connection between globalization and the acceleration of demographic and geopolitical turbulence ... The long view that global history can offer helps us to see that no phase of globalization, or global connectedness, can be permanent. Globalization is always a work in progress, subject to reversals, transitions, crises, and breakdowns. No global order, whether economic or geopolitical, has been fixed for long. ${ }^{73}$

Turning to the present with that in mind, it is important to disentangle the American-led international order from the experience of globalization that has prevailed recently. As noted above, not all international orders are equally conducive to globalization. Take the Cold War as an example. During that period, the United States and the Soviet Union imposed a global balance of power that, however narrowly, avoided direct military confrontation. Yet despite a relatively stable bipolar international order, this was a case of competing systems with minimal economic or cultural exchange between them. While elements of the current international order, notably the United Nations and the Bretton Woods institutions, date from the immediate post-war years, even the American-led "Free World" of the Cold War-constrained by capital controls, limited travel, and entrenched protectionism—was not especially globalized. 
Granted, the origins of contemporary globalization can be traced to the rise of transnational corporations and growing integration between Western Europe, North America, and Japan in the second half of the 2oth century. ${ }^{74}$ But the transformation of the global economy wrought by freer trade, financialization, and China's economic opening lay in the future. ${ }^{75}$

Only with the fall of the Berlin Wall did the American-dominated liberal order, characterized by accelerating globalization encompassing ever more of the planet, truly emerge. During this unipolar moment, as John Mearsheimer argues, American hegemony allowed for the previously "bounded order" limited to the industrialized West to become fully "liberal and international," though at the cost of diluting and weakening its core political elements. ${ }^{76}$ G. John Ikenberry similarly observes that, "the postwar liberal order did not begin as a global order. It was built 'inside' half of a bipolar system as part of a larger geopolitical project ... When the Cold War ended this inside order became the outside order ... Liberal internationalism was globalized." 77 In other words, U.S. hegemony after 1989 provided the foundation for an international order favorable to increasing integration and interdependence on a global scale. Over the next three decades hundreds of millions of people escaped subsistence poverty, powerful new technologies conquered the globe, air travel and migration soared, and integrated transnational supply chains produced more and cheaper consumer goods. ${ }^{78}$ At the same time, however, unchallenged American power courted hubris and overstretch, economic dislocation disrupted traditional industries, notably the manufacturing base that had underpinned the industrial Western economies, transnational integration provoked defenses of traditional cultures and beliefs, and non-state actors like terrorist organizations acquired new means of communication and destruction. ${ }^{79}$

74 Hopkins, American Empire, 701.

75 On financial globalization in the 1980s, see James Boughton, "Globalization and the Silent Revolution of the 1980s." Finance \& Development 39 (1) (2002), 40-43.

76 John Mearsheimer, "Bound to Fail: The Rise and Fall of the Liberal International Order." International Security 43 (4) (2019), 8.

77 G. John Ikenberry, A World Safe for Democracy: Liberal Internationalism and the Crises of Global Order (New Haven: Yale University Press, 2020), 257.

78 Hal Brands and Francis J. Gavin, "Covid-19 and World Order." In Covid-19 and World Order, 4-5; Patrick Porter, The False Promise of Liberal Order (Cambridge: Polity Press, 2020), 147148; G. John Ikenberry, Liberal Leviathan: The Origins, Crisis, and Transformation of the American World Order (Princeton: Princeton University Press, 2011), 221-222. See also Hal Brands, Making the Unipolar Moment: U.S. Foreign Policy and the Rise of the Post-Cold War Order (Ithaca: Cornell University Press, 2016).

79 On these trends, see David Goodhart, The Road to Somewhere: The Populist Revolt and the Future of Politics (London: Hurst \& Company, 2017); Jorge Heine and Ramesh Thakur, eds. 
Perhaps most significantly, the "rise of the rest" - particularly the exponential growth of China since its admission to the World Trade Organization in 2001accelerated the emergence of an increasingly "post-American" international system. ${ }^{80}$

Herein lies a paradox, but one explicable in the global historical terms discussed above: that American hegemony in the post-Cold War era facilitated a process of globalization that in turn contributed to the rapid emergence of new centres of economic, political, and military power and thus the relative decline of the United States' geostrategic position. American policy missteps, especially the 2003 Iraq War and the 2007-2008 financial crisis, surely accelerated this process. ${ }^{81}$ But the return of China to great power status, second only to the United States and with a larger economy measured in terms of purchasing power parity, is a world-historical development that is difficult to imagine absent the near-symbiotic U.S-China economic relationship that prevailed in recent decades. ${ }^{82}$ While China hid its strength and bided its time, it became a low-wage manufacturing powerhouse with ample savings, a growing middle class, and an appetite for U.S. debt. Conversely, while the U.S. government took on a growing number of international military obligations, American consumers enjoyed cheap Chinese goods and a credit-fuelled boom. ${ }^{83}$

But this state of affairs is quickly receding into the past. Even before the emergence of Covid-19, geopolitical factors were already driving the U.S. and China apart. This is to some degree the inexorable logic of geopolitics, or what Graham Allison has called "Thucydides's trap," whereby a rising power seeks to challenge and ultimately displace the incumbent. ${ }^{84}$ As Christopher Coker

The Dark Side of Globalization (New York: United Nations University Press, 2011); Ikenberry, A World Safe for Democracy, 255-285; Porter, The False Promise of Liberal Order, 137-152; and Dani Rodrik, The Globalization Paradox: Democracy and the Future of the World Economy (New York: W.W. Norton, 2011).

8o Fareed Zakaria, The Post-American World (New York: W.W. Norton \& Co., 2008). See also Mearsheimer, "Bound to Fail," 8; and Ian Bremmer and Nouriel Roubini, "A G-Zero World." Foreign Affairs 9o (2) (2011), 2-7.

81 Brands and Gavin, "Covid-19 and World Order," 5.

82 Graham Allison, "China Is Now the World's largest Economy. We Shouldn't Be Shocked." The National Interest, October 15, 2020.

83 On the U.S.-China economic relationship during this period, see Niall Ferguson and Moritz Schularick, "'Chimerica' and the Global Asset Market Boom." International Finance 10 (3) (2007), 215-239 and "The End of Chimerica: Working Paper 10-037," Harvard Business School (2009), 1-31. On the U.S.-China rapprochement, see Margaret MacMillan, Nixon and Mao: The Week That Changed the World (New York: Random House, 2007).

84 Graham Allison, Destined for War: Can America and China Escape Thucydides's Trap? 
observed in 2015, "despite asserting that great power war is unthinkable, China and the United States are still preparing for it ... The United States is a status quo power whose instincts, though they may often lead to war and conflict, are not necessarily belligerent. The same does not apply in the case of China." ${ }^{\prime 85}$ Indeed, since 2012 Chinese President Xi Jinping has pursued an assertive Chinese grand strategy alongside an increasingly totalitarian domestic system, prompting international anxiety over the scope of the Chinese Communist Party's (CCP) global ambitions. ${ }^{86}$ Aggressive Chinese actions and territorial claims in the South China Sea, over Taiwan, and on its Himalayan border with India, in addition to repression in Xinjiang and Hong Kong, suggest a growing willingness to challenge what the CCP regards as a fast-declining United States. ${ }^{87}$ This dovetails with the Belt and Road Initiative (BRI), the centrepiece of Xi's foreign policy, which aims to create a global economic and infrastructure network with China at its core. As Julian Gewirtz shrewdly observes, the BRI shows that "China is not deglobalizing so much as it is de-Americanizing." 88 China's long-standing "Great Firewall," moreover, has always implied a bifurcated internet with immense economic and security implications-especially considering Beijing's policy of "civil-military fusion," its pervasive intellectual property theft, and the strategic significance of so-called "dual-use" digital technologies. ${ }^{89}$ Altogether, this can be seen as an attempt to compete geopolitically with the United States - and eventually displace it as the leading power in Asia if not globally_-by fashioning a new, Sinocentric globalized system under a resurgent Chinese empire. ${ }^{90}$ "In other words," as Peter Frankopan writes, "the

(Boston: Houghton Mifflin Harcourt, 2017). See also John Mearsheimer, The Tragedy of Great Power Politics (New York: W.W. Norton, 2014 [2001]).

85 Christopher Coker, The Improbable War: China, the United States, and the Logic of Great Power Conflict (Oxford: Oxford University Press, 2015), 2, 6.

86 Avery Goldstein, "China's Grand Strategy under Xi Jinping." International Security 45 (1) (2020), 193-199.

87 Julian Gewirtz, "China Thinks America Is Losing: Washington Must Show Beijing It's Wrong." Foreign Affairs 99 (6) (2020), 62-72.

88 Gewirtz, "China Thinks America is Losing," 70.

89 Josh Chin, "The Internet, Divided Between the U.S. and China, Has Become a Battleground," Wall Street Journal, February 9, 2020; Alex Joske, "Picking flowers, making honey: The Chinese military's collaboration with foreign universities." Australia Strategic Policy Institute, October 3o, 2018; Amja Manuel and Kathleen Hicks, "Can China's Military Win the Tech War?" Foreign Affairs, July 29, 2020. On the implications of digital technologies for warfare, see Christopher Coker, Warrior Geeks: How 21st Century Technology is Changing the Way We Fight and Think About War (Oxford: Oxford University Press, 2013).

9o As Arne Westad writes: "China ... is a de facto empire that tries to behave as if it were a nation-state." Odd Arne Westad, "The Sources of Chinese Conduct." Foreign Affairs 98 
[new] Silk Roads are everywhere-not just in Central Asia but across all of Asia, Africa, Europe, and the Americas ... All roads used to lead to Rome. Today, they lead to Beijing." ${ }^{\prime 1}$ In this context, American policymakers have woken up to China's strategic challenge - a rare instance of bipartisan agreement in Washington. ${ }^{92}$

The fallout from Covid-19 has only accelerated this development. While the United States' reputation has suffered as a result of its poor handling of the crisis, as well as internal polarization and instability, the CCP's initial coverup of the outbreak and subsequent disinformation campaign has contributed to growing public hostility in North America, Europe, Australia, and Japan. ${ }^{93}$ Western dependence on China for personal protective equipment, essential medical supplies, and technological components has fuelled calls to extricate strategic supply chains from the country. ${ }^{94}$ And China's economic blackmail and aggressive "wolf warrior" diplomacy — which intensified during the pandemic, most notably when Beijing lashed out at Australia's call for an independent international inquiry into the origins of Covid-19 - appears to be backfiring. ${ }^{95}$ Whether Beijing's increasing belligerence derives from over-confidence, opportunism, or even fear, it is hard to imagine globalization and the international order returning to the status quo ante - and still less the relatively benign period of the 199os and early 200os - once the pandemic has passed.

(5) (2019), 88. On the BRI as an empire-building project, see Jonathan E. Hillman, The Emperor's New Road: China and the Project of the Century (New Haven: Yale University Press, 2020).

91 Peter Frankopan, The New Silk Roads: The New Asia and the Remaking of the World Order (New York: Vintage Books, 2020 [2018]), 86.

92 Philippe le Corre, "The Eu's New Defensive Approach to a Rising China." Carnegie Endowment for International Peace, July 1, 2020; Kathrin Hille and Richard Waters, "Washington unnerved by China's 'civil-military fusion.'” Financial Times, November 8, 2018; Wajahat Khan and Masaya Kato, "China's rise forges new bond between Japan and Five Eyes." Nikkei Asia, August 7, 2020; Josh Rogin, "We must find bipartisanship on the China issue." Washington Post, May 27, 2020.

93 Laura Silver, Kat Devlin, and Christine Huang, "Unfavorable Views of China Reach Historic Highs in Many Countries." Pew Research Center: Global Attitudes and Trends, October 6, 2020.

94 Simon Denyer, "Japan helps 87 companies to break from China after pandemic exposed overreliance." Washington Post, July 21, 2020; Kathrin Hille, "The great uncoupling: one supply chain for China, one for everywhere else." Financial Times, October 6, 2020.

95 Jo Kim, "Why China's Propaganda Efforts So Often Backfire." The Diplomat, April 24, 2020; Alexandra Ma, “China's new, handline 'wolf warrior' diplomacy is supposed to cement its dominance — but it's also uniting its rivals abroad and dividing people at home." Business Insider, June 27, 2020; Ian Young, "China unleashed 'wolf warrior' diplomacy on Canada. It may have backfired." South China Morning Post, 21 October 2020. 
This points to a second paradox: that the Covid-19 pandemic is both a product and a solvent of the system of globalization and international order that has prevailed since 1989. An un-globalized world in which China, among others, was still overwhelmingly rural and disconnected would not have been so conducive to the rapid emergence and global spread of a novel pathogen originating in Wuhan. The ironic result is that a pandemic facilitated by connectivity and integration, especially the explosion of long-haul air travel and tourism in recent decades, is aggravating geopolitical tensions likely to hasten at least some degree of economic decoupling. Indeed, it seems probable that the Covid-19 pandemic will accelerate a significant pre-existing trend: the emergence of two competing, though in some places overlapping, economic and strategic systems-one centred on the United States and the other on China.

This could mean, in effect, the return of empire. "Such a world," as Michael Beckley observes, "would see the return of great-power mercantilism and new forms of imperialism ... powerful countries would once again try to reduce their economic insecurity by establishing exclusive economic zones, where their firms could enjoy cheap and secure access to raw materials and large captive consumer markets." ${ }^{96}$ In some areas, notably ecommerce, 5 G networks, artificial intelligence, and telecommunications supply chains, this already appears to be happening. ${ }^{97}$ "After Xi came to power," Julian Gewirtz notes, "he made it a priority to address the dangers of interdependence, including through the 'Made in China 2025' initiative, which aims to make China 70 percent self-sufficient in ten core technologies by the year 2025." What is more, "the Covid-19 pandemic has underscored to many in China the advantages" of its "state-dominated economic model." ${ }^{98}$ And as Christopher Coker has written, "The desire of states to preserve their information sovereignty is becoming a major policy issue in what is threatening to become a new Cold War. Two sharply defined technological and online systems are emerging which may well ... determine the future shape of cyber conflict from espionage to warfare."99

96 Michael Beckley, "Rogue Superpower: Why This Could Be an Illiberal American Century." Foreign Affairs 99 (6) (2020), 83.

97 Christine Fox and Thayer Scott, "Flat No Longer: Technology in the Post-Covid World" and Janice Gross Stein, "Take It Off-Site: World Order and International Institutions after Covid-19." In Covid-19 and World Order, chs. 9 \& 14.

98 Gewirtz, "China Thinks America is Losing," 66-68.

99 https://www.lse.ac.uk/News/Latest-news-from-LSE/2021/a-Jan-21/The-West-needs-to-res pond-to-Chinas-bid-for-technology-dominance-New-report. For the report, see "Protect, Constrain, Contest: Approaches for Coordinated Transatlantic Economic and Technological Competition with China." LSE IDEAS China Foresight Project, January 2021. 
In the coming months and years, then, economic exchange between the two emerging systems will likely continue to be reshaped and even curtailed by strategic calculations as the United States and China seek greater geopolitical and geo-economic autonomy. This may be a portentous development, but the refashioning of globalization amid geopolitical turbulence is hardly surprising in the light of global history.

\section{5}

\section{Conclusion}

The Covid-19 pandemic has clearly exacerbated what has already been dubbed "Cold War II" while "at the same time revealing its existence to those who ... doubted it was happening." 100 Yet there are important differences between contemporary U.S.-China competition and the decades-long standoff between Moscow and Washington. First among these is that China's economic challenge to the United States is far more serious than the Soviet Union's ever was. ${ }^{101}$ Another is that Washington and Beijing are starting from a position of deep economic integration, and both are likely to remain highly globalized within as well as to some degree across their respective systems. This will entail very different national security implications from the Cold War. ${ }^{102} \mathrm{~A}$ better, though disconcerting, historical analogy for the U.S.-China rivalry might be the late-19th and early-2oth century antagonism between Britain and Germany, with economic power measured in telecommunications rather than industrial prowess, military supremacy decided not by dreadnoughts but in cyberspace, and with Taiwan playing the role of Belgium. ${ }^{103}$

Of course, one of the limits of applied history is that no historical analogy can be exact. Nuclear weapons add a crucial element that did not exist in 1914, while the character of contemporary global capitalism differs in important

\footnotetext{
100 Niall Ferguson, "From Covid War to Cold War: The New Three-Body Problem." In Covid-19 and World Order, 420.

101 Niall Ferguson, "The New Cold War? It's With China, and It Has Already Begun," New York Times, December 2, 2019.

102 On the security implications of integration, see Henry Farrell and Abraham L. Newman, "Weaponized Interdependence: How Global Economic Networks Shape State Coercion." International Security 44 (1) (2019), 42-79.

103 Graham Allison, "The next great war." Washington Post, November 9, 2018. See also Michèle Flournoy, "How to Prevent a War in Asia: The Erosion of American Deterrence Raises the Risk of Chinese Miscalculation." Foreign Affairs, June 18, 2020; Richard Haass and David Sacks, "American Support for Taiwan Must be Unambiguous: To Keep the Peace, Make Clear to China That Force Won't Stand." Foreign Affairs, September 2, 2020.
} 
ways from 100 years ago. ${ }^{104}$ But regardless of the historical parallel, it is difficult to avoid the conclusion that the present moment in international politics represents a crisis of globalization as described above, in which "the interaction between its various components triggered unmanageable tensions or when the 'manic' phase of economic expansion gave way to ... geopolitical turbulence."105 Navigating this environment this will be the primary strategic challenge for the United States in the post-Covid-19 world. Thankfully, one of the few clearcut lessons of history is that no outcome is preordained. Underlying structural trends certainly matter, but so too do the choices and decisions of policymakers, who can seek to shape, though scarcely control, the interplay of economic and geopolitical forces. There is no returning to the unipolar moment, but neither is China poised to imminently displace the United States as the world's preeminent power. Despite recent events, Washington can still draw on immense economic, cultural, and military reserves, including a vast network of allies and partners unmatched in history. Informed and judicious policymaking, in other words, has scope to mould the future. This will be imperative if the U.S. hopes to avoid the unthinkable catastrophe of a great power war and preserve as much as possible the benefits of globalization in the international order to come.

To that end, an enlightened American grand strategy should seek to better understand the interests and perspectives of both China and U.S. allies, as well as the shifting character of the international system, regardless of the specific policies employed. Here historical knowledge will be indispensable. ${ }^{106}$ But such an effort cannot simply engage historians of U.S. foreign relations. Other countries and cultures — not least China, with a self-image as the Middle Kingdom and East Asia's predominant power stretching back millennia-have distinct histories and traditions of international politics that are separate from and in some cases long predate their relations with the United States. ${ }^{107}$ Any grand strategy worth the name, moreover, needs to comprehend processes of

104 At that time, for instance, Britain was a prolific exporter of people and capital, whereas the contemporary United States is both a debtor nation and a leading destination for immigrants. For a critical discussion of global capitalism and hegemonic transitions, see Giovanni Arrighi and Beverly J. Silver, "Capitalism and World (Dis)order." Review of International Studies 27 (Dec. 2001), 257-279.

105 Darwin, "Afterword: History on a Global Scale," 179.

106 As Graham Allison and Niall Ferguson have argued, now "is time for a new and rigorous 'applied history.'" Graham Allison and Niall Ferguson, "Why the U.S. President Needs a Council of Historians." The Atlantic, September 2016.

107 For China's perspective on global history, for instance, see Dominic Sachsenmaier, Global Perspectives on Global History: Theories and Approaches in a Connected World (Cambridge: Cambridge University Press, 2011), 172-231. 
integration and interconnectedness, and the complex and evolving relationship between globalization and geopolitics. While there is no one-size-fits-all methodology for applying history to foreign policy, a global historical perspective is perhaps uniquely suited to offer a "historical sensibility" that is attuned to "the powerful hold that history exerts on other cultures, leaders, and nations," as well as the broad sweep of historical change and contingency on a planetary scale. ${ }^{108}$ Familiarity with global history can thus help to cultivate strategic empathy as well as the long-term perspective that is essential to the development of grand strategy. But applied history is a two-way street. If policymakers and International Relations scholars are expected to learn from history, it is incumbent upon historians to meet them halfway. Global history, as I have tried to show, can bring important insights to bear on contemporary strategic and international affairs - but only if its practitioners will engage on those issues, and enter the arena of applied history.

\section{Acknowledgments}

I would like to thank Sven Beckert, Susan Colbourn, Leonardo Davoudi, Simon Miles, the fellows and faculty associates of Harvard's Weatherhead Initiative on Global History, and this journal's anonymous reviewers for their helpful comments on previous drafts of this article. My former colleagues at Global Affairs Canada, notably Jessica Becker, and the Oxford Centre for Global History, with whom I enjoyed many stimulating conversations, also shaped its development. Errors and misapprehensions, of course, are mine alone.

108 Francis J. Gavin, "Thinking Historically: A Guide for Strategy and Statecraft." War on the Rocks, November 19, 2019. 